\title{
貴族日記にみえる平安・鎌倉時代貴族住宅の末尾語「亭」について ON THE LAST WORD “TEI” OF HEIAN AND KAMAKURA PERIOD ARISTOCRACY RESIDENCE IN THE NOBLE DIARY
}

\author{
劉羽虹 ${ }^{* 1}$, 藤 田勝也 ${ }^{* 2}$ \\ Yuhong LIU and Masaya FUJITA
}

\begin{abstract}
As part of a study on the comparison and transition of architectural terms between Japan and China. The purpose of this study is to clarify the actual condition of the residence term “Tei” (亭) that can be seen in the noble diaries from Heian to the early Kamakura period in Japan. This paper based on 20 noble diaries. In order to clarify the actual condition of “Tei” (亭), it is essential to compare it with “Tei” (第).
\end{abstract}

Keywords : Noble diary, Residence terms, Tei, Tei 貴族日記，住宅用語，亭，第

\section{1. はじめに}

本研究の目的は、日中間の建築用語の比較と変遷に関する研究の 一環として、日本のおもに平安から鎌倉時代前半における貴族住宅 の末尾語「亭」について、その実態を詳細に明らかにすることにあ る。

筆者らは同時期の史書をもとに、未尾語「殿」がもつ意味の変化 について明らかにし 1）2）、た「亭」の実態についても史書をもと に検証した ${ }^{3}{ }^{4}$ )。本稿はとくに後者の「亭」について、貴族日記に 対象を広げることによって、その実態をより深く解き明かそうとす るものである。

本稿に関連寸る既往研究として挙げられるのは、星陽介氏らや宮 田充氏らによる報告である。

まず星氏らは、多くの貴族日記をもとに、「亭」や「第」を末尾語 に用いる住宅について、居住者の階層に注目して検討している5)。 具体的には「第」「亭」の記載件数の割合が示寸傾向をもとに時期区 分していて、第 1 期は 10 世紀初頭から 11 世紀中期頃、第 2 期は 11 世紀中期頃から 12 世紀中期頃、第 3 期は 12 世紀中期頃以降であ り、第 1 期では末尾語「第」を多用し、また高位貴族の住宅に集中 する傾向にあり、第 2 期には、「第」よりも「亭」を多用し、第 3 期 には、第 2 期の傾向が続くとした。ただし、星氏らが取り上げた貴 族日記のうち、『台記』『葉』『燊』『岡屋関白記』については、

「亭」「第」に関して詳細な分析はなく、居住者の階層性も明らかで ない。星氏らが主張する「第」から「亭」への変転の時期について も再検証の必要がある。

また宮田氏らはとくに『玉葉』を取り上げ、住宅名の末尾語の用 法について検証結果を報告している ${ }^{6}$ 。『玉葉』での末尾語「亭」は、 平安初期にはそれほど広範囲に用いられず、幅広く使われるのは平 安末期であるという。また同一邸でも「亭」「第」の両方を用いる事
例があることを指摘する。しかしその背景や要因には言及しない。

さて前記したとおり、筆者らは平安・鎌倉時代の貴族住宅の末尾 語「亭」について、史書『百錬抄』『吾妻鏡』をもとに分析、報告し た 3） 4)。末尾語「亭」を用いる初期の住宅は池や泉など「水」との 関連が深いこと、また 12 世紀後半が末尾語「第」から「亭」への転 換期であることなどを推論、考察したが、その妥当性の検証には貴 族日記に対象を広げることが不可欠である。そこで本稿では、星氏 らが取り上げた貴族日記に加えて『水左記』『山槐記』『愚昧記』『勘 仲記』そして『仙洞御移徙部類記』を新たに考察対象とした（表 1 )。 また、末尾語「殿」がそうであったように、さらには上記の既往研 究からも導かれる通り、本稿でも「第」との比較という視角から末 尾語「亭」の動向を跡付けたい。

Table1 A list of historical 表 1 史料表

\begin{tabular}{|c|c|c|c|c|c|}
\hline 史料名Historical records & 筆者Auther & 西暦A.D. & 史料名Historical records & 筆者Auther & 西暦A.D. \\
\hline $\begin{array}{l}\text { 小右記* } \\
\text { Shovulki }\end{array}$ & $\begin{array}{l}\text { 藤原実資 } \\
\end{array}$ & 978-1032 & $\begin{array}{l}\text { 山笼記 } \\
\text { Sankaiki }\end{array}$ & 中山忠親 & $1151-1194$ \\
\hline 権記* & 藤原行成 & 991-1011 & 玉葉 ${ }^{*}$ & 九条兼実 & $1114-1200$ \\
\hline Gonki & FUJIWARA no Yukinari & $991-1011$ & Gyokuyo & KUJO Kanezane & $1104-1<00$ \\
\hline 春記* & 藤原資房 & $1038-1054$ & 愚昧記 & 藤原実房 & $1167-1189$ \\
\hline Shunki & FUJIWARA no Sukefusa & & Gumaiki & FUJIWARA & \\
\hline 水左記 & 源俊房 & 1062.1108 & 明月記 ${ }^{*}$ & 藤原定家 & $1180-1235$ \\
\hline Suisaki & MINAMOTO no Toshifusa & & Meigetsuki & FUJIWARA no Teika & \\
\hline 帥記* & 源経信 & 1065-1088 & 猪险関白記 & 藤原家実 & $1199-1211$ \\
\hline Sochiki & MINAMOTO no Tsunenobu & & Inokuma kanoaku ki & FUJIWARA no & \\
\hline $\begin{array}{l}\text { 後二条師通記 } \\
\text { Gonijo Moromichi ki }\end{array}$ & $\begin{array}{l}\text { 藤原師通 } \\
\text { FUJWARA no Moromichi }\end{array}$ & 1083-1099 & $\begin{array}{l}\text { 玉檠* } \\
\text { Gyokuzui }\end{array}$ & $\begin{array}{l}\text { 藤原道家 } \\
\text { FUJIWARA no }\end{array}$ & $1209-1238$ \\
\hline 中右記* & 藤原宗忠 & $1087-1132$ & 岡屋関白記 ${ }^{*}$ & 近衛兼経 & $1222-1251$ \\
\hline Chuyuki & FUJIWARA no Munetada & $1087-1138$ & Okanoya kanpaku ki & KONOE Kanetsune & \\
\hline $\begin{array}{l}\text { 殿暦* } \\
\text { Denraku }\end{array}$ & 藤原忠実 & 1098-1118 & 民経記* & 藤原経光 & $1226-1267$ \\
\hline & $\begin{array}{l}\text { FUJINARA no Tadazane } \\
\text { 平信範 }\end{array}$ & & & & \\
\hline Heihanki & TAIRA no Nobunori & 1132-1171 & Kanchuki & FUJIWARA no & $1274-1300$ \\
\hline $\begin{array}{l}\text { 台記* } \\
\text { Daiki }\end{array}$ & $\begin{array}{l}\text { 藤原頼長 } \\
\text { FUJWARA no Yorinaga }\end{array}$ & $1136-1155$ & $\begin{array}{l}\text { 仙洞御移徙部類記 } \\
\text { Sentogoishiburuiki }\end{array}$ & $\begin{array}{c}\text { (伏見宮旧蔵) } \\
\text { Hushiminiya }\end{array}$ & $1022-1270$ \\
\hline
\end{tabular}

$「 * 」$ は星氏らが対象とした史料
関西大学大学院理工学研究科 修士 (文学) 関西大学 教授・工博
Grad. Student, Graduate School of Science and Engineering, Kansai University, M.A. Prof., Kansai University, Dr.Eng. 


\section{2. 貴族日記にみえる「亭」と「第」の記事数の推移}

本稿で対象とした貴族日記（表 1) について、邸名に末尾語「亭」

「第」を用いた記事数の推移を年単位で図化した（図 1)。「第」は 薄い灰色、「亭」はやや濃い灰色、同じ年に「亭」と「第」の両方が 確認できる事例は黒で示した。

「亭」の初見は『小右記』正暦元年（990）10月 3 日条の「摂政 亭」(藤原道隆邸) である。11 世紀の後半以降、「亭」の記事数は増 加する。『台記』『玉葉』では「亭」「第」の両方を用いる事例が多い。 いっぽう『猪隈関白記』では末尾語「亭」の事例は管見では皆無で ある。

図 1 を俯瞰すると、左半は「第」、右半は「亭」が優勢で、1100 年 前後を境に、およそ 11 世紀後半から 12 世紀前半頃が「第」から 「亭」への転換期となったようにみえる。『仙洞御移徙部類記』の記 事数と記事の密度は限定的かつ散在的だが、前半は「第」、後半は「亭」 というおおよその傾向は看取でき、上記の傾向とほぼ整合的である。

いっぽうの「第」は全体を通して断続的に確認できるが、10 世紀 中頃から 11 世紀後半にかけて多く見られる。その後は「亭」が多く を占めるものの、12 世紀中頃以降、再び増加傾向にある。

\subsection{0、11 世紀の「亭」「第」について}

貴族日記の 10、11 世紀にみえる「第」「亭」の記事数を「里亭」 「彼亭」などを除外してまとめたのが表 2 である注1)。小右記』『権 記』『春記』は「第」が圧倒し、『権記』『春記』では「亭」が確認で きない。逆に『帥記』『後二条師通記』『中右記』では「亭」が圧倒 し、『後二条師通記』では「第」がみえない。

『小右記』（藤原実資 957-1046）の末尾語「亭」とは、前記し た藤原道隆の「摂政亭」のほか、藤原道長の「左府亭」注 2)、藤原頼 通の「関白亭」「関白書亭」「書亭」注3)「六条関白旅亭」である。い ずれも従一位、正二位の高位貴族の邸である。なお「六条関白旅亭」 の「旅亭」は、史書の分析で夕た『吾妻鏡』における「中納言法橋

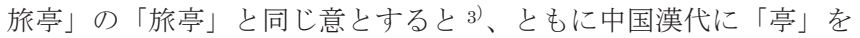

Table2 Number of "Tei" and "Tei" seen in 10th and 11th centuries 表 2 10、11 世紀にみえる「亭」「第」の記事数

\begin{tabular}{|l|l|l|l|l|l|l|l|}
\hline $\begin{array}{l}\text { 史料名 } \\
\text { Historical records }\end{array}$ & $\begin{array}{l}\text { 小右記 } \\
\text { Shoyuki }\end{array}$ & $\begin{array}{lll}\text { 権記 } \\
\text { Gonki }\end{array}$ & $\begin{array}{l}\text { 春記 } \\
\text { Shunki }\end{array}$ & $\begin{array}{l}\text { 水左記 } \\
\text { Suisaki }\end{array}$ & $\begin{array}{l}\text { 帥記 } \\
\text { Sochiki }\end{array}$ & $\begin{array}{l}\text { 後二条師通記 } \\
\text { Gonijo Moromichi ki }\end{array}$ & $\begin{array}{l}\text { 中右記 } \\
\text { Chuyuki }\end{array}$ \\
\hline $\begin{array}{l}\text { 第/亭 } \\
\text { Tei/Tei }\end{array}$ & $158 / 8$ & $33 / 0$ & $20 / 0$ & $6 / 4$ & $3 / 26$ & $0 / 16$ & $2 / 107$ \\
\hline
\end{tabular}

「やどり」とする古い用例に通じるものである。

『小右記』における「第」の事例では、藤原道長や頼通の邸が半 数以上を占める。同一邸について「亭」「第」の両方を用いる事例も ある。「摂政亭」と「摂政第」、「左府亭」と「左府第」、「関白亭」と 「関白第」であり、「第」は「亭」がそうであるように、従一位、正 二位の高位貴族の邸である。

『権記』（藤原行成 972-1028）での「第」の事例でも、正三位 までの高位貴族である。従四位下の「左近中将藤原朝臣第」が唯一 の例外である。

『春記』（藤原資房 1007-1057）での「第」の事例でも、藤原頼 通（従一位）の「博陸第」「高倉第」「関白第」「執柄第」、藤原教通 (正二位) の「内大臣二条第」といったように高位貴族であり、藤 原資頼注 4）の「資頼五条第」が唯一の例外である。

『水左記』(源俊房 1035-1121) の「亭」の事例についてみると、 源俊房（従二位）の「六條亭」、源顕房（正二位）の「皇后宮大夫六 條亭」、藤原師実（従一位）の「関白亭」のように、高位貴族の邸で ある。いっぽう「第」は、藤原師実（従一位）の「東三條第」「関白 第」、「御所院二條第」などであり、藤原師実邸には「亭」「第」の両 方を用いている。

『帥記』（源経信 1016-1097）の「第」の3 例は、いずれも源師 房 (正二位) の邸である。また「亭」は、藤原俊家 (正二位) の「戸 部御亭」、藤原敦家（正四位下）の「敦家朝臣六條亭」、藤原実綱（正 四位下）の「実綱朝臣亭」、源俊房（正二位）の「大宮大夫土御門」 である。「亭」は「第」より幅広い位階で用いていることになる。

『後二条師通記』（藤原師通１062-1099）の「亭」は、藤原師実

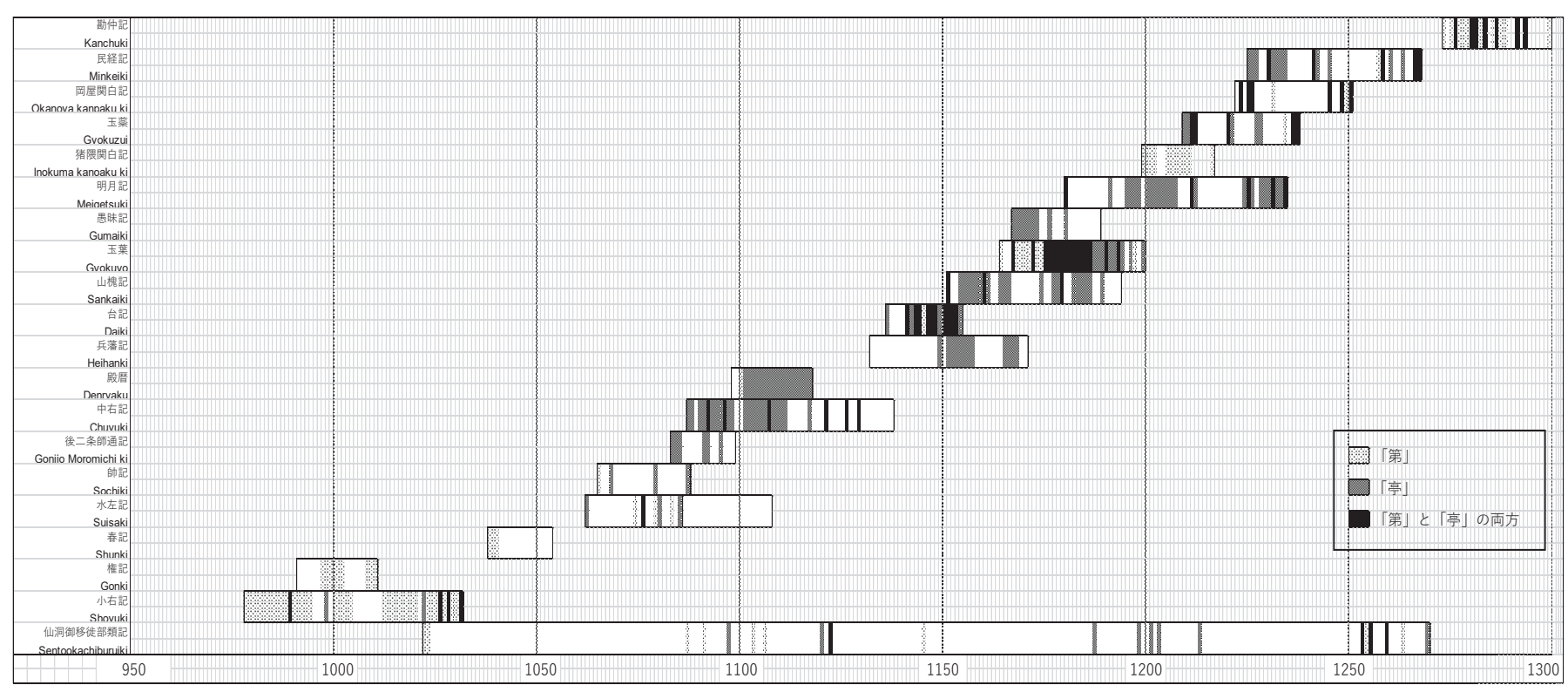

Fig.1 The change of number of 'Tei' and 'Tei' cases in noble diaries

図 1 貴族日記における「亭」「第」の記事数の推移 
Table3 The cases of 'Tei' of "Chuyuki"

表 3 『中右記』における「亭」の事例

3-1 The cases of 'Tei' in the $11^{\text {th }}$ century (11 世紀)

\begin{tabular}{|c|c|c|}
\hline 住宅名 Name of Residence ～～～ & 人物 figures & 位階ikai \\
\hline $\begin{array}{l}\text { 右府六条亭Ufu rokujo Tei、六条亭Rokujo Tei、右府土御門亭Ufu tsuchimikado Tei、右大将六条亭Udaisho rokujo Tei、右 } \\
\text { 将軍六条亭Ushogun rokuio Tei，右大臣亭Udaiiin Tei，右大臣六条亭Udaiiin rokuio Tei }\end{array}$ & 源顕房MINAMOTO no Akifusa & $\begin{array}{l}\text { 正二位 } \\
\text { Shonii }\end{array}$ \\
\hline 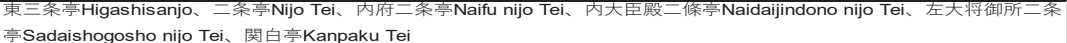 & 藤原師通FUJIWARA no Moromichi & $\begin{array}{l}\text { 正二位 } \\
\text { Shonii }\end{array}$ \\
\hline 関白二条亭Kanpaku nijo Tei、新造九条亭Shinzo kujo Tei & 藤原師通FUJIWARA no Moromichi & 従一位Juichii \\
\hline 左府亭Safu Tei、土御門亭Tsuchimikado Tei、左大臣土御門亭Sadaijin tsuchimikado Tei、左府土御門亭Safu tsuchimikado & 源俊房MINAMOTO no Toshifusa & 正二位Shonii \\
\hline 左府亭Safu Tei & 源俊房MINAMOTO no Toshifusa & 従一位Juichii \\
\hline 土御門亭Tsuchimikado Tei & 藤原宗俊FUJIWARA no Munetoshi & 正二位Shonii \\
\hline 九条前太相国亭Kujo sakinodaishokoku Tei & 藤原信長FUJIWARA no Nobunaga & 従一位Juichii \\
\hline 二条烏丸故関白旧亭Nijokarasuma kokanpaku kyutei & 藤原教通FUJIWARA no Norimichi & 従一位Juichii \\
\hline 関白殿六条亭Kanpakudono rokujo Tei、関白亭Kanpaku Tei & 藤原師実FUJIWARA no Morozane & 従一位Juichii \\
\hline 太后御所六条坊門亭Taiko gosho rokujobomon Tei & 太后Taiko & \\
\hline 新造高松亭Shinzo takamatsu Tei、高松亭Takamatsu Tei & 藤原顕季FUJIWARA no Akisue & 正四位下Shoshiinoge \\
\hline 頼綱朝臣六条亭Yoritsuna ason rokujo Tei & 源頼網MINAMOTO no Yoritsuna & 従四位下Jushinoge \\
\hline 修理大夫俊綱朝臣臥見亭Shuri no daibu toshitsuna ason husimi Tei & 橘俊綱TACHIBANA no Toshitsuna & 正四位上Shoshiinojo \\
\hline 八条亭Hachijo Tei & 藤原宗通FUJIWARA no Munemichi & 正四位下Shoshiinoge \\
\hline 右大将土御門亭Udaisho tsuchimikado Tei、右大将亭Udaisho Tei & 源雅実MINAMOTO no Masazane & 正二位Shonii \\
\hline 帥大納言亭Sochi dainagon Tei & 源経信MINAMOTO no Tsunenobu & 正二位Shonii \\
\hline 上卿新中納言亭Shokei sinchunagon Tei、新中納言亭Sinchunagon Tei & 藤原通俊FUJIWARA no Michitoshi & 正三位Shosanmi \\
\hline 治部卿亭Jibukyo Tei & 藤原通俊FUJIWARA no Michitoshi & 従二位Junii \\
\hline 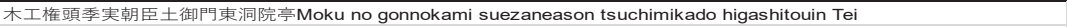 & 藤原季実FUJIWARA no Suezane & 従四位上Jushiinojo \\
\hline 江中納言亭Gochunagon Tei & 大江匡房OE no Masafusa & 従二位Junii \\
\hline 右兵衛督亭Uhyoe no kami Tei & 源雅俊MINAMOTO no Masatoshi & 従三位Jusanmi \\
\hline 源中納言亭Genchunagon Tei & 源俊実MINOMOTO no Toshisane & 従二位Junii \\
\hline 因幡内侍里亭Inabanaishi ritei & 藤原惟子FUJIWARA Iko & \\
\hline 和泉守有信宅五条亭|zuminokami arinobutaku gojo Tei & 藤原有信FUJIWARA no Arinobu & 従五位下 Jugoinoge \\
\hline
\end{tabular}

3-2 The cases of 'Tei' in the $12^{\text {th }}$ century (12 世紀)

\begin{tabular}{|c|c|c|}
\hline $\begin{array}{l}\text { 内大臣亭Udaijin Tei、内府亭Naifu Tei、内大臣土御門亭Naidaijin tsuchimikado Tei、左大将亭Sadaisho Tei、近衛高倉亭 } \\
\text { Konoe karakura Tei、御所内府土御門亭Goshono }\end{array}$ & 源雅実MINAMOTO no Masazane & 正二位Shonii \\
\hline 民部亭Minbu Tei、民部卿亭Minbukyo Tei & 源俊明MINAMOTO no Toshiaki & 正二位Shonii \\
\hline 左府亭Safu Tei、左府里亭Safu ritei、左大臣亭Sadaijin Tei、左大臣堀川亭Sadaijin horikawa Tei & 源俊房MINAMOTO no Toshifusa & 従一位Juichii \\
\hline 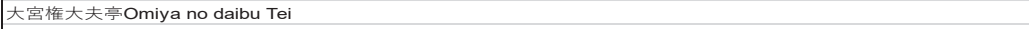 & 藤原季仲FUJIWARA no Suenaka & 従二位Junii \\
\hline 江中納言二条亭Gochunagon nijo Tei & 大江匡房OE no Masafusa & 正二位Shonii \\
\hline 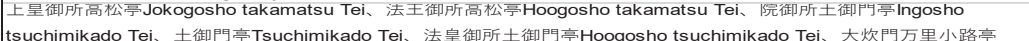 & 上皇御所Jokogosho & \\
\hline 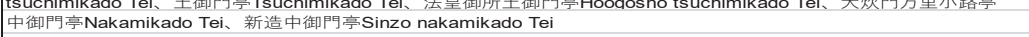 & 藤原忠宗FUJIWARA no Tadamune & 正三位Shosanmi \\
\hline 故為章朝臣二条亭Kotameaki ason nijo Tei & 高階為章TAKASINA no Tameaki & 正四位下Shoshiinoge \\
\hline 為房朝臣九条亭Tamefusa ason kujo Tei & 藤原為房FUJIWARA no Tamefusa & 正四位下Shoshiinoge \\
\hline $\begin{array}{l}\text { 右衛門督六条亭Uemon no kami rokujo Tei、右衛門督宗通卿五節出立所東洞院亭Uemon no kami munemichikyo } \\
\text { gosechidedachiio higashitoin Tei、右衛門督亭Uemon no kami Tei }\end{array}$ & 藤原宗通FUJIWARA no Munemichi & 正二位Shonii \\
\hline 右大将花山院亭Udaisho kazanin Tei、右大将土御門亭Udaisho tsuchimikado Tei、右大将亭Udaisho Tei & 藤原家忠FUJIWARA no letada & 正二位Shonii \\
\hline 春宮大夫亭Togu no daibu Tei、春宮大夫三条亭Togu no daibu sanjo Tei & 藤原公実FUJIWARA no Kinzane & 正二位Shonii \\
\hline 三条富小路亭Sanjo tominokoji Tei & 藤原盛実FUJIWARA no Morizane & 正四位下Shoshiinoge \\
\hline 五条烏丸地相博頼仲入道中御門亭Gojo karasumachi sohaku yorinaka nyudo nakamikado Tei & 源頼仲MINAMOTO no Yorinaka & 従五位下Jugoinoge \\
\hline 有佐朝臣三条亭Arisuke ason sanjo Tei & 藤原有佐FUJIWARA no Arisuke & 従五位下Jugoinoge \\
\hline $\begin{array}{l}\text { 前斎院御所二条堀川亭Sakinosaiin nijo horikawa Tei、前斎院二条亭Sakinosaiin nijo Tei、御所堀川二条亭Gosho } \\
\text { horikawaniio T前斎院御所中御門亭Sakinosain qosho nakanomikado Tei }\end{array}$ & 令子内親王Reishi naishinnou & \\
\hline 四郎大夫宗重亭Shirodayu muneshige Tei & 藤原宗重FUJIWARA no Muneshige & 従五位下Jugoinoge \\
\hline 関白亭Kanpaku Tei & 藤原忠実FUJIWARA no Tadazane & 正二位Shonii \\
\hline 源中納言亭Genchunagon Tei & 源俊実MINOMOTO no Toshisane & 従二位Junii \\
\hline 東宮御所土御門亭Togugosho tsuchimikado Tei & 東宮御所Togugosho & \\
\hline 左大弁中御門亭Sadaiben nakanomikado Tei、左大弁亭Sadaiben Tei & 源重資MINAMOTO no Sinasuge & 正四位上Shoshiinojo \\
\hline 修理大夫六条亭Shuri no daibu rokujo Tei & 藤原顕季FUJIWARA no Akisue & 従三位Jusanmi \\
\hline 法橋成信五条富小路亭Houkyo narinobu gojo tominokoji Tei & 法橋成信HOUKYO Narinobu & 僧Buddhist \\
\hline 皇居内大臣土御門亭Koukyo naidaijin tsuchimiakdo Tei & \multicolumn{2}{|l|}{ 皇居Koukyo/源雅実MINAMOT } \\
\hline 京御所三条烏丸亭Kyogosho sanjo karasuma Tei & 御所Gosho & \\
\hline
\end{tabular}

（従一位）の「堀河亭」、藤原実季（正二位）の「七条亭」そして、 記主師通の自邸「二条亭」であり、「二条亭」が記事数 13 を数え、 もっとも多い。

『中右記』(藤原忠宗 1087-1133) における末尾語「亭」の記事 数は 252、「第」は 7 である。それらについて、居住者不明の場合は 除外し、また同一人で同一邸は事例数 1 とみなして年次順にまとめ た（11 世紀は表 3-1、12 世紀は表 3-2）7）。表中に太線で区切った のは同一人で位階が異なる場合である。

『中右記』の 11 世紀における「亭」の記事数は 107、「第」は 2 であり、「亭」を多用している。居住者の位階についてみると、「亭」 は従一位から従五位下まで幅広い（表 3-1)。いっぽう「第」は、藤 原行家（正四位下）の「行家朝臣七条第」および、藤原家忠（正二 位）の「権大納言近衛第」である。

以上、10、11 世紀に「亭」は少なく「第」を多用する、という星 氏らの主張をあらためて確認した。また「第」は高位貴族に用いる と星氏らはされたが、しかし『小右記』によれば「亭」でもそれは 該当した。また 11 世紀中頃より「亭」を多用するというのは星氏ら の指摘の通りである。ただし用いる階層は「第」と同様に広範囲で
あった。さらに特徵的なのは、『後二条師通記』で記主師通の自邸に 「亭」を多用していることである (「二条亭」)。これは末尾語として の「亭」の謙譲表現としての性格を示唆する。

なお、史書による検証では、未尾語「亭」は、当初、池や泉など 「水」の存在でよく知られる邸に用いた可能性があるとした 3） 4)。 はたして「亭」の早い事例である『小右記』における道隆の「摂政 亭」もまた、南池の存在が知られているし8、ほかにも末尾語「亭」 の住宅で「水」の存在する事例は複数確認できる注 5 )。しかし史料的 制約による不明の事例も少なからずあり、史書はもとより貴族日記 からも、可能性の域を出るものではない。

\section{12 世紀の「亭」「第」について}

貴族日記の 12 世紀にみえる「第」「亭」の記事数について、「里 亭」「彼亭」などを除外してまとめたのが表 4 である。『台記』『玉 葉』以外は「亭」が大勢を占める。

『中右記』の 12 世紀における「亭」の記事数は 145 、対して「第」 はわずか 5 である。居住者の位階に注目すると、「亭」は従一位から 従五位下まで幅広く（表 3-2）、女院、前斎院、上皇の御所などもあ 
Table4 Number of "Tei" and "Tei" seen in 12th centuries 表 412 世紀にみえる「亭」「第」の記事数

\begin{tabular}{|c|c|c|c|c|c|c|c|}
\hline $\begin{array}{l}\text { 史料名 } \\
\text { Historical records }\end{array}$ & $\begin{array}{l}\text { 中右記 } \\
\text { Chuyuki }\end{array}$ & $\begin{array}{l}\text { 殿暦 } \\
\text { Denryaku }\end{array}$ & $\begin{array}{l}\text { 兵範記 } \\
\text { Heihanki }\end{array}$ & $\begin{array}{l}\text { 台記 } \\
\text { Daiki }\end{array}$ & $\begin{array}{l}\text { 山槐記 } \\
\text { Sankaiki }\end{array}$ & $\begin{array}{l}\text { 玉葉 } \\
\text { Gyokuyo }\end{array}$ & $\begin{array}{l}\text { 愚昧記 } \\
\text { Gumaiki }\end{array}$ \\
\hline $\begin{array}{l}\text { 第/亭 } \\
\text { Tei/Tei }\end{array}$ & $5 / 145$ & $1 / 80$ & $0 / 153$ & $88 / 42$ & $3 / 166$ & $115 / 174$ & $0 / 63$ \\
\hline
\end{tabular}

る。いっぽう「第」について居住者が判明するのは、藤原忠通（従 一位）の「近衛第」、「皇居六条第」、「皇居土御門烏丸第」、「皇居土 御門第」そして上皇御所の「三条烏丸第」である。また鳥羽上皇の 三条邸については、未尾語「亭」「第」の両方を用いている注6)。

前節の『後二条師通記』がそうであったように、『中右記』でも記 主忠宗の自邸が「中御門亭」というように末尾語「亭」を用いてい て、しかも記事数 40 と多い。

『殿暦』(藤原忠実 1078-1162) では「亭」が 80 に対して、「第」 は 1 のみである。「亭」の位階に注目すると、従一位から正四位下ま で幅広く注 7)、女院の御所「中宮三条亭」「皇后宮二条亭」、上皇の御 所「高松亭」「六条亭」「院御所大炊御門亭」「高陽院亭」などもある。

「第」は源雅実（正二位）の「内大臣大饗第」である。

また『殿暦』でも記主忠実の自邸三条邸について記す場合はすべ て (記事数 8)、「三条亭」のように「亭」を用いている。

『兵範記』(平信範 1112-1187) は「亭」を用い、第」は管見に 見えない。「亭」は従一位から正四位下までと幅広く注8)、また女院 藤原得子の邸が「八条東洞院泉亭」である。

『台記』(藤原頼長 1120-1156) でも「亭」が多いが、「第」が希 少というわけではない。ただし前半は「亭」を多用し、後半は「第」 が増える傾向にある。

「亭」は、源有仁（従一位）の「左相府亭」、藤原忠通（従一位） の「摂政亭」「執柄亭」「摂政近衛亭」「近衛亭」、藤原公教 (正二位) の「左金吾亭」、藤原頼長 (従一位) の「左府亭」、源雅定 (正二位) の「左大将亭」「右大臣亭」など、従一位、正二位の高位貴族の邸で ある。いっぽう末尾語「第」は、従一位から従五位上まで幅広く注 9)、 また上皇御所の「中院第」「新造高松第」や仮皇居の「四條東洞院第」、 官子内親王の「前齋院東洞院第」、女院御所の「高陽院土御門東洞院 第」「三條第」「三條西洞院第」「土御門第」などがある。また藤原忠 通や源雅定の邸では「亭」「第」の両方を用いている注 10)。

さらに、頼長の自邸についてみると、「大炊第」「大炊亭」「大炊御 門第」「大炊御門亭」といったように、『後二条師通記』や『中右記』 とは異なり、「亭」とともに「第」も用いている。

星氏らは、『台記』における記主頼長の邸について、平安時代の中・ 後期（約 1150 年以降）にかけて「大炊御門亭」から「大炊第」のよ うに「亭」から「第」へと変化したと主張する5)。しかし、管見で は 12 世紀後半に「大炊亭」は記事数 6、「大炊第」は記事数 7 を確 認していて、「亭」「第」を併用していたのが実状である。

『山槐記』(中山忠親 1131-1195) は「亭」が 166 と大半を占め、 「第」は 3 のみである。

「亭」について、居住者不明の事例は除外し、また同一人の同一 邸は事例数 1 とみなして年次順にまとめたのが表 5 である 7)。事例 数では 73 となるが、居住者の位階に注目寸ると、従一位から正五 位下まで幅広く、以仁王の邸もある。また表 5 を通覧すると、平清 盛および清盛に関わる人物の邸が目立つ注 11)。これは史書『百錬抄』
Table5 The cases of 'Tei' in "Sankaiki"

表 5 『山槐記』における「亭」の事例

\begin{tabular}{|c|c|c|c|c|}
\hline & 西暦A.D. & 住宅名 & 入物 & 位階 \\
\hline $\begin{array}{l}\text { Jabanese Calendar } \\
\text { 仁平2年2月9日 }\end{array}$ & 1152 & $\begin{array}{l}\text { Name of Residence } \\
\text { 若大章 }\end{array}$ & 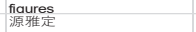 & 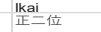 \\
\hline & 1152 & $\begin{array}{l}\text { Udaiiin Tei } \\
\text { 左倡紊 }\end{array}$ & $\begin{array}{l}\text { MiNAMOTO no } \\
\text { 滕頉長 }\end{array}$ & 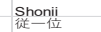 \\
\hline 仁平2年2月9日 & 1152 & 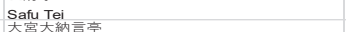 & FUJIWARA no Yorinaaa & 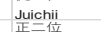 \\
\hline 仁平2年3月13日 & 1152 & Omiva dainagon Tei & $\begin{array}{l}\text { FUJIWARA no Koremichi } \\
\text { P山罱粯 }\end{array}$ & i Shonii \\
\hline 仁平2年9月15日 & 1152 & $\begin{array}{l}=1 \text { 條宁 } \\
\text { Sanio Tei }\end{array}$ & NAKAYAMA Tadachika & $\begin{array}{l}\text { 歨五位 } \\
\text { a Shoaoinode }\end{array}$ \\
\hline 仁平2年9月19日 & 1152 & Naifu Tei & $\begin{array}{l}\text { FuJWARA no } \\
\text { Fus: }\end{array}$ & $\begin{array}{l}\text { 歨一位 } \\
\text { Shonii }\end{array}$ \\
\hline 久寿 2 年 6 月 1 日 & 1155 & 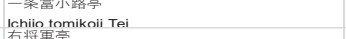 & $\begin{array}{l}\text { 德大寺公親 } \\
\text { TOKuDill Kinchika }\end{array}$ & $\begin{array}{l}\text { 正四位下 } \\
\text { Shoshiinoae } \\
\text { 正一位na }\end{array}$ \\
\hline 保元4年正月30日 & 1159 & $\begin{array}{l}\text { Ushoqun Tei } \\
\text { Usto }\end{array}$ & $\begin{array}{l}\text { FuUIWARA no Kinvoshi } \\
\text { Fulvi }\end{array}$ & $\begin{array}{l}\text { IE-1픈 } \\
\text { Shonii }\end{array}$ \\
\hline 永暦1年7月9日 & 1160 & Sanio takakura Tei & 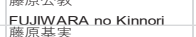 & Shonii \\
\hline 永暦1年10月11日 & 1160 & $\begin{array}{l}\text { 執恼亭 } \\
\text { Shipe Tei }\end{array}$ & 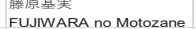 & $\begin{array}{l}\text { 正二位 } \\
\text { Shonii }\end{array}$ \\
\hline 永攵1年11月15日 & 1160 & $\begin{array}{l}\text { 入道太相国八條亭 } \\
\text { Nududo taishokhiio Tei }\end{array}$ & $\begin{array}{l}\text { 滕原实行 } \\
\text { Fu na Sanevuki }\end{array}$ & $\begin{array}{l}\text { 従一位 } \\
\text { Juichii }\end{array}$ \\
\hline 永暦1年12月4日 & 1160 & $\begin{array}{l}\text { 右大臣亭 } \\
\text { Udai }\end{array}$ & $\begin{array}{l}\text { 滕原公能 } \\
\text { UullWARA no Kinvoshi }\end{array}$ & $\begin{array}{l}\text { 正二位 } \\
\text { Shonii }\end{array}$ \\
\hline 永暦1年12月4日 & 1160 & $\begin{array}{l}\text { 入道前太政監亭 } \\
\text { Naiodailin Tei }\end{array}$ & $\begin{array}{l}\text { 滕原 } \\
\text { FUIWARA no Sanevuki }\end{array}$ & 従一位 \\
\hline 永攵1年12月 4 日 & 1160 & $\begin{array}{l}\text { 太政大臣亭 } \\
\text { Daili dei diin Tei }\end{array}$ & $\begin{array}{l}\text { 藤原伊通 } \\
\text { FUIWA no Koremichi }\end{array}$ & 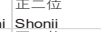 \\
\hline 伈保1年8月11日 & 1161 & 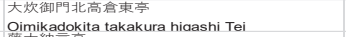 & $\begin{array}{l}\text { 藤原公能 } \\
\text { FUIW no Kinvoshi }\end{array}$ & Shonii \\
\hline 応保1年9月11日 & 1161 & $\begin{array}{l}\text { 藤大納言索 } \\
\text { Fuil dainaon Tei }\end{array}$ & $\begin{array}{l}\text { 滕原公能 } \\
\text { FUIWARA no Kinvoshi }\end{array}$ & $\begin{array}{l}\text { 是二位 } \\
\text { Shonii }\end{array}$ \\
\hline 応保1年11月18日 & 1161 & $\begin{array}{l}\text { 内府亭 } \\
\text { Naifu Tei }\end{array}$ & $\begin{array}{l}\text { 藤原宗能 } \\
\text { FUIWARA no }\end{array}$ & $\begin{array}{l}\text { 正二位 } \\
\text { Shonii }\end{array}$ \\
\hline 応保1年11月19日 & 1161 & $\begin{array}{l}\text { 入道太相国亭 } \\
\text { Nvudo taishoku Tei }\end{array}$ & $\begin{array}{l}\text { 滕原害行 } \\
\text { FUIWARA no Sanevuki }\end{array}$ & Juichii \\
\hline 応保1年11月19日 & 1161 & $\begin{array}{l}\text { 入道右大臣亭 } \\
\text { Nvado udaiin Tei }\end{array}$ & $\begin{array}{l}\text { 源雅定 } \\
\text { MNOTO no }\end{array}$ & $\begin{array}{l}\text { 昰二位 } \\
\text { Shonii }\end{array}$ \\
\hline 応保1年11月19日 & 1161 & $\begin{array}{l}\text { 内大臤勇 } \\
\text { Naiin Tei }\end{array}$ & $\begin{array}{l}\text { 滕原宗能 } \\
\text { FUIWARA no }\end{array}$ & $\begin{array}{l}\text { 正二位 } \\
\text { Shonii }\end{array}$ \\
\hline 永万2年7月27日 & 1166 & $\begin{array}{l}\text { 㩧政崇 } \\
\text { Sessho Tei }\end{array}$ & 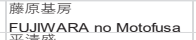 & $\begin{array}{l}\text { 是=位 } \\
\text { Shonii }\end{array}$ \\
\hline 仁安2年2月2日 & 1167 & $\begin{array}{l}\text { 内府亭 } \\
\text { Nafu Tei }\end{array}$ & $\begin{array}{l}\text { 平清盛 } \\
\text { TAR Kivomori }\end{array}$ & $\begin{array}{l}\text { 正二位 } \\
\text { Shonii } \\
\text { Shon }\end{array}$ \\
\hline 仁安2年2月11日 & 1167 & 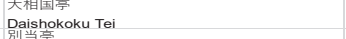 & $\begin{array}{l}\text { 平清盛 } \\
\text { TA no Kivomori }\end{array}$ & $\begin{array}{l}\text { 正二位 } \\
\text { Shonii } \\
\text { 步位 }\end{array}$ \\
\hline 仁安2年2月14日 & 1167 & 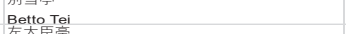 & $\begin{array}{l}\text { FUIWARA no Takasue } \\
\text { FulW }\end{array}$ & $\begin{array}{l}\text { 步=11i } \\
\text { Shosanmi }\end{array}$ \\
\hline 仁安2年4月14日 & 1167 & 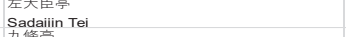 & $\begin{array}{l}\text { 滕原経察 } \\
\text { FUurA no }\end{array}$ & $\begin{array}{l}\text { 正二位 } \\
\text { Shonii }\end{array}$ \\
\hline 仁安2年4月27日 & 1167 & 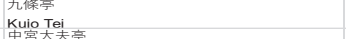 & $\begin{array}{l}\text { 滕原師長 } \\
\text { FUנINARA no Moronaaa }\end{array}$ & 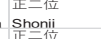 \\
\hline 安元1年8月16日 & 1175 & 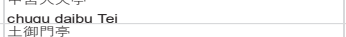 & 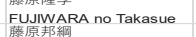 & Shonii \\
\hline 安元1年8月20日 & 1175 & $\begin{array}{l}\text { Isuchimikado Tei } \\
\text { Tsure }\end{array}$ & FUNIWARA no Kunituna & $\begin{array}{l}\mathbb{1}-1 \text {-1 } \\
\text { Shonii } \\
\text { and }\end{array}$ \\
\hline 治承2年正月20日 & 1178 & $\begin{array}{l}\text { 入道大相国提津福原亭 } \\
\text { Nyudo dukuhara Tei }\end{array}$ & $\begin{array}{l}\text { 平清盛 } \\
\text { TANo Kivomori }\end{array}$ & $\begin{array}{l}\text { 従一位 } \\
\text { Juichii }\end{array}$ \\
\hline 治承2年6月27日 & 1178 & $\begin{array}{l}\text { 七條坊城亭 } \\
\text { Nanatio boio Tei }\end{array}$ & $\begin{array}{l}\text { 滕原光隆 } \\
\text { FUUIWA no Mitsutaka }\end{array}$ & $\begin{array}{l}\text { 正二位 } \\
\text { Shonii }\end{array}$ \\
\hline 治承2年6月28日 & 1178 & $\begin{array}{l}\text { 右大搏亭 } \\
\text { Uddisho Tei }\end{array}$ & $\begin{array}{l}\text { 平宗盛 } \\
\text { TAI no Munemori }\end{array}$ & $\begin{array}{l}\text { 正二位 } \\
\text { Shonii }\end{array}$ \\
\hline 治承2年閏6月27日 & 1178 & 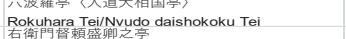 & 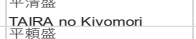 & $\begin{array}{l}\text { 促-1位 } \\
\text { Juichii } \\
\text { 正位 }\end{array}$ \\
\hline 治承2年11月12日 & 1178 & 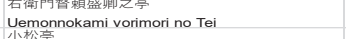 & TAIRA no Yorimori & 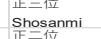 \\
\hline 治承3年正月6日 & 1179 & Komatsu Tei & FUJWARA no Motomichi & 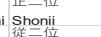 \\
\hline 治承3年正月22日 & 1179 & Dairi Tei & TAIRA no Tokitada & Junii \\
\hline 治承3年2月2日 & 1179 & $\begin{array}{l}\text { 左大将亭 } \\
\text { Sada }\end{array}$ & 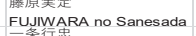 & $\begin{array}{l}\text { 歨一位 } \\
\text { shonii } \\
\text { sit) }\end{array}$ \\
\hline 治承3年2月24日 & 1179 & 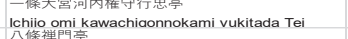 & ICHIJO Yukitada & 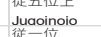 \\
\hline 治承3年3月18日 & 1179 & 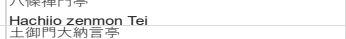 & TAIRA no Kivomori & $\begin{array}{l}\text { Juichii } \\
\text { Juti } \\
\text { 正一位 }\end{array}$ \\
\hline 治承3年3月26日 & 1179 & 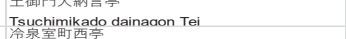 & 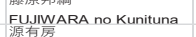 & 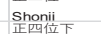 \\
\hline 治承3年4月9日 & 1179 & Reizei muromachi Tei & $\begin{array}{l}\text { MINAMOTO no Arifusa } \\
\text { 平清盛 }\end{array}$ & $\begin{array}{l}\text { Shoshinoge } \\
\text { Shour }\end{array}$ \\
\hline 治承3年4月23日 & 1179 & Nudo daishokoku hachiio Tei & 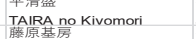 & $\begin{array}{l}\text { 㐾一位 } \\
\text { Juichi } \\
\text { 従一位 }\end{array}$ \\
\hline 治承3年4月25日 & 1179 & 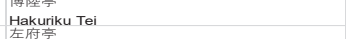 & $\begin{array}{l}\text { FUUIWARA no Motofusa } \\
\text { 藤原経宗 }\end{array}$ & Juichii \\
\hline 治承3年5月24日 & 1179 & $\begin{array}{l}\text { 工ctivi } \\
\text { Safu Tei } \\
\text { 五條亭 }\end{array}$ & 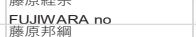 & 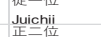 \\
\hline 治承3年6月12日 & 1179 & 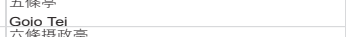 & 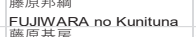 & 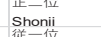 \\
\hline 治承3年6月20日 & 1179 & Rokuio sessho Tei & $\begin{array}{l}\text { 滕原基房 } \\
\text { Funva no Motofusa }\end{array}$ & 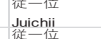 \\
\hline 治承3年11月14日 & 1179 & Hachilo Tei & TAIRA no Kivomori & 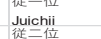 \\
\hline 治承3年11月16日 & 1179 & 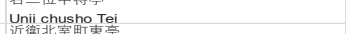 & FUUIVARA no Motomichi & i 捉位 \\
\hline 治承3年11月26日 & 1179 & 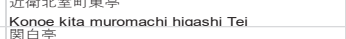 & 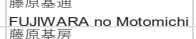 & $\begin{array}{l}\text { 促三位 } \\
\text { i Juni } \\
\text { 征一位 }\end{array}$ \\
\hline 治承3年12月13日 & 1179 & 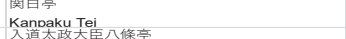 & $\begin{array}{l}\text { FUUIVARA no Motofusa } \\
\text { 平清盛 }\end{array}$ & 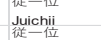 \\
\hline 治承3年12月16日 & 1179 & Nvudo daiiodailin hachilo Tei & $\begin{array}{l}\text { PAl: } \\
\text { TARA no Kivomori }\end{array}$ & 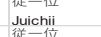 \\
\hline 治承4年2月21日 & 1180 & 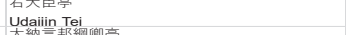 & 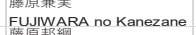 & 従一位 \\
\hline 治承4年3月4日 & 1180 & $\begin{array}{l}\text { 大納言邦網卿亭 } \\
\text { Dainag }\end{array}$ & $\begin{array}{l}\text { 滕原邦網 } \\
\text { FUIW no Kunituna }\end{array}$ & Shonii \\
\hline 治承4年3月9日 & 1180 & $\begin{array}{l}\text { 摄政亭 } \\
\text { Sessho Tei }\end{array}$ & FUJIWARA no Motor & ii Shonii \\
\hline 治承4年3月16日 & 1180 & 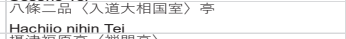 & $\begin{array}{l}\text { 平清盛 } \\
\text { TAIA no Kivomori }\end{array}$ & Juichii \\
\hline 治承4年3月19日 & 1180 & 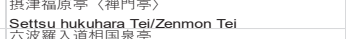 & 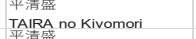 & 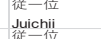 \\
\hline 治承4年3月22日 & 1180 & 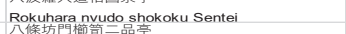 & TAIRA no Kivomori & Juichii \\
\hline 治承4年4月6日 & 1180 & 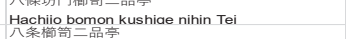 & $\begin{array}{l}\text { TARA no Kivomori } \\
\text { TA清盛 no }\end{array}$ & 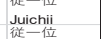 \\
\hline 治承4年4月27日 & 1180 & 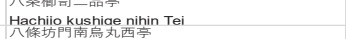 & TAIRA no Kivomori & $\begin{array}{l}\text { Juichin } \\
\text { Ju西位下 }\end{array}$ \\
\hline 治承4年5月14日 & 1180 & $\begin{array}{l}\text { Hachio bomon minami karasuma nishi Tei } \\
\text { Fin }\end{array}$ & $\begin{array}{l}\text { FUJWARA no Suevoshi } \\
\text { W }\end{array}$ & Shoshinoae \\
\hline 治承4年5月15日 & 1180 & Sanio kita takakura nishi Tei & Mochinitoou & \\
\hline 治承4年5月26日 & 1180 & $\begin{array}{l}\text { 前右大将〈宗盛〉 } \\
\text { Sakino } \\
\text { San }\end{array}$ & TAIRA No Munemori & 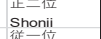 \\
\hline 治承4年5月30日 & 1180 & $\begin{array}{l}\text { 福原亭 } \\
\text { Fuka Tei } \\
\text { Funara Tei }\end{array}$ & $\begin{array}{l}\text { 平清盛 } \\
\text { TA n Kivomori }\end{array}$ & $\begin{array}{l}\text { 従一位 } \\
\text { Juichii }\end{array}$ \\
\hline 治承4年11月10日 & 1180 & 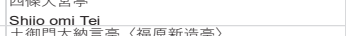 & FulinaRA no Takasue & $\begin{array}{l}\frac{1}{1}-1 \text { - } \\
\text { Shonii } \\
-1\end{array}$ \\
\hline 治承4年11月20日 & 1180 & $\begin{array}{l}\text { 土eif } \\
\text { Tsuchimikado dainaaon Tei/Fukuhara sinzo Tei }\end{array}$ & 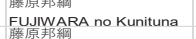 & $\begin{array}{l}\text { 歨一位 } \\
\text { Shonii } \\
\text { 正一位 }\end{array}$ \\
\hline 治承4年11月20日 & 1180 & & FUJIWARA no Kunituna & $\begin{array}{l}\text { 歨一位 } \\
\text { Shonii }\end{array}$ \\
\hline 治承4年11月26日 & 1180 & $\begin{array}{l}\text { 五條東洞院亭 } \\
\text { Goio hin Tei }\end{array}$ & $\begin{array}{l}\text { 藤原邦網 } \\
\text { Fü no Kunituna }\end{array}$ & $\begin{array}{l}\text { 正二位 } \\
\text { Shonii }\end{array}$ \\
\hline 治承4年11月26日 & 1180 & $\begin{array}{l}\text { Tish } \\
\text { Rokuhara nvudo daishokoku Tei }\end{array}$ & TARA no Kivomori & Juichii \\
\hline 治承4年12月14日 & 1180 & 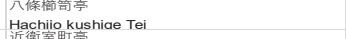 & $\begin{array}{l}\text { 平清盛 } \\
\text { TAIR Kivomori }\end{array}$ & $\begin{array}{l}\text { 従一位 } \\
\text { juichii }\end{array}$ \\
\hline 元攵1年8月20日 & 1184 & Konoe muromachi Tei & $\begin{array}{l}\text { FUJIWARA no Motomichi } \\
\text { FUIVA }\end{array}$ & i Juichii \\
\hline 元暦1年8月24日 & 1184 & 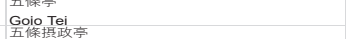 & 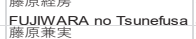 & 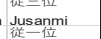 \\
\hline 元暦2年7月9日 & 1185 & 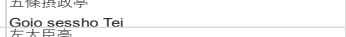 & $\begin{array}{l}\text { 滕泉 } \\
\text { FüNARA }\end{array}$ & Juichii \\
\hline 元攵2年7月22日 & 1185 & Sadailin Tei & 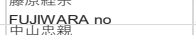 & 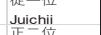 \\
\hline 文治1年8月19日 & 1185 & Chuzan Tei & NAKAYAMA Tadachika & shonii \\
\hline 文治5年11月13日 & 1189 & $\begin{array}{l}\text { Sadailin Tei } \\
\text { Sade }\end{array}$ & $\begin{array}{l}\text { 滕泉UIWARA } \\
\text { FUJWesad no }\end{array}$ & Shonii \\
\hline
\end{tabular}


の分析でも指摘した点である注 12 。

いっぽう「第」は藤原宗能（正二位）の「内府第」、藤原邦綱（正 二位）の「土御門第」である。

また『山槐記』の記主中山忠親の自邸については、「三条亭」「中 山亭」といったように、「第」ではなく「亭」を用いている。

『玉葉』(九條兼実 1149-1207) での「亭」の記事数は 174、「第」 は 115 であり、「亭」の方が多いが、「第」も一定程度あって希少と いうわけではない。

末尾語「亭」の事例は、従一位から従四位上まであり注 13)、暲子 内親王の「八條東洞院亭」や女院藤原殖子の「三條烏丸亭」といっ た事例がある。いっぽう「第」もまた従一位から従五位下まで幅広 く注 14)、また、皇居や東宮御所、親王邸にも用いられている。そし て同一邸に「亭」「第」の両方を用いる事例もある注15)。

『玉葉』を分析した宮田氏らは ${ }^{6)}$ 、当初は「第」を多用するが、 やがて「第」は減り、かわって「亭」が増えるという、「第」から「亭」 への変転を主張する。ただし図 1 の『葉』の欄に示される通り、 変転の途中には両者併用の時期が見いだせる。

また、兼実の自邸についてみると、記事数で「九條亭」17、「九條 第」 4 であり、また泠泉北万里小路西や大炊御門北富小路西の邸に ついても「冷泉亭」「大炊御門亭」といったように、「第」（あるいは 「家」）も無いことはないが、「第」よりも「亭」を多用する傾向に あったことがわかる。

『愚昧記』(藤原実房 1147-1125) では、「亭」を用い「第」は見 えない。そして多くは従一位から従四位上までの貴族邸である注 16 )。

『明月記』(藤原定家 1162-1241) の 12 世紀は、「亭」が記事数 9、「第」は 2 である。「亭」は従一位、正二位の貴族邸注 17)のほか、 平清盛の妻時子の「八条坊門匣亭」がある。いっぽう「第」は、平 頼盛（正三位）の邸が「八条室町頼盛卿第」である。

星氏らは『中右記』『殿暦』『兵範記』をもとに、11 世紀中頃から 12 世紀中頃に「第」から「亭」へと代わると主張する。本稿で取り 上げた『山槐記』『思昧記』もその主張にほぼ整合的である。しかし さらに本稿で取り上げた『台記』『葉』では、いささか様相が異な る。『台記』では「第」を「亭」とともに用い、両者の区別はあいま いであり、『葉』では日記それ自体に「第」から「亭」への変転が ある。

また『中右記』『殿暦』『山槐記』そして『玉葉』では、記主の自 邸に「亭」を多用したことが注目される。前三者は記事数で「亭」 が「第」を圧倒するので、「亭」を用いることと、それが自邸である ことの関係性は不明確である。しかし「第」を一定程度用い、「亭」 と「第」の区別があいまいにみえる『葉』において、自邸に「亭」 が多いのは示唆的である。

\section{13 世紀の「亭」「第」について}

貴族日記の 13 世紀にみえる「第」「亭」の記事数について、「里 亭」「彼亭」などを除外してまとめたのが表 6 である。

『明月記』の 13 世紀は「亭」を多用する。「亭」の事例は従一位、 正二位、従二位の高位貴族の邸で注 ${ }^{18)}$ 。上皇や女院の御所もある。 正四位下の藤原親能の「大宮亭」が唯一の例外である。

「第」もまた、藤原道家 (正二位) の「執柄第」、近衛兼経（正二 位）の「近衛二品新第」で、高位貴族である。
Table6 Number of "Tei" and "Tei" seen in $13^{\text {th }}$ centuries 表 613 世紀にみえる「亭」「第」の記事数

\begin{tabular}{|c|c|c|c|c|c|c|}
\hline $\begin{array}{l}\text { 史料名 } \\
\text { Historical records }\end{array}$ & $\begin{array}{l}\text { 明月記 } \\
\text { Meigetsuki }\end{array}$ & $\begin{array}{l}\text { 猪隈関白記 } \\
\text { Inokuma kanoaku ki }\end{array}$ & $\begin{array}{l}\text { 玉苜 } \\
\text { Gyokuzui }\end{array}$ & $\begin{array}{l}\text { 岡屋関白記 } \\
\text { Okanoya kanpaku ki }\end{array}$ & $\begin{array}{l}\text { 民経記 } \\
\text { i Minkeiki }\end{array}$ & 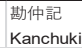 \\
\hline 䇫/亮 & $6 / 124$ & $93 / 0$ & $20 / 41$ & $26 / 14$ & $27 / 166$ & $129 / 8$ \\
\hline
\end{tabular}

『猪隈関白記』（藤原家実 1179-1243）は「第」を用い、管見に 「亭」は皆無である。未尾語「第」の事例は皇居や院御所、皇親の 御所注 19) や、従一位、正二位の高位貴族邸である注 20)。他の日記で は「亭」を用いてもよいと考えられる邸でも、『猪隈関白記』では「第」 である。たとえば、ほぼ時期を同じくする『明月記』では藤原頼実 の邸を「前太相国大炊御門亭」とするが、『猪涱関白記』では「前太 相国大炊御門第」である注 21)。

『玉策』(藤原道家 1193-1252) では「亭」が多いが、「第」も 用いている。「亭」の事例は従一位から正四位下まで注 22 )、「第」は 従三位までであり注 23)、「亭」は「第」よりやや幅広い階層ともいえ る。しかし両方を用いる場合もあり注 24)、その差異は判然としない。

『岡屋関白記』(近衛兼経 1210-1259) でも「亭」が「第」より 多い。「亭」の事例は、従三位以上の高位貴族邸注 25$)$ 、第」もまた従 一位、正二位、従二位の高位貴族邸注 ${ }^{26}$ ) や、皇居・親王邸である。 「亭」が「第」より広範ともいえるが両者に大差はない。はたして 同一邸に「亭」「第」両方の事例がみられる注 27)。

『民経記』(広橋経光 1213-1274) では「亭」が「第」を圧倒す る。「亭」の事例は、従一位から従四位下までの貴族邸で注 28)、右馬 允（七位相当）藤原宣俊の邸の「青侍亭」は唯一の例外である。ほ かに僧官の「綱所来弁亭」、中宮九条竴子の「中宮一条室町亭」「一 条室町亭」、女院平棟子の「女房一品亭」がある。いっぽう「第」は 従一位から正五位上の貴族邸であり主 29)、「亭」との区別はあいまい である。はたして同一邸に「亭」「第」の両方を用いる事例がある注 $30)$ 。

『勘仲記』(広橋兼仲 1244-1308) では「第」が「亭」を圧倒す る。「第」の事例は従一位から従六位上まで幅広く注31)、女院西園寺 姞子の「常葉井第」、女院勘解由小路経子の「歓喜光院内侍殿第」が ある。いっぽう「亭」は皇居や貴族邸である注 32 )。「第」は「亭」よ り広範囲ともいえるが、「亭」は記事数 8 と少なく、「亭」と「第」 の区別はあいまいである。ここでも「亭」「第」の両方を用いる事例 があるが、管見では吉田経長の「吉田亭」「吉田第」、西園寺実兼の 「春宮大夫亭」「春宮大夫第」の 2 例のみである。

星氏らは、「亭」を多用する傾向は 12 世紀中頃以降も継続すると 主張する 5)。しかし、本節で通覧した 13 世紀の様相は、この主張に 否定的である。「亭」「第」のいずれかが支配的になるというわけで はなく、両方が用いているというのが実態に近い。

また個別に日記を見ると、『猪隈関白記』『勘仲記』は「第」、『明 月記』『民経記』は「亭」である。「亭」か「第」のいずれを用いる かは、記主の個性による面もあるかもしれない。亭」が支配的な『民 経記』において、その晚年近くに限って「第」が頻出するのは、あ るいはこの仮説を裏打ちするものであろう。

\section{6. おわりに}

以上、貴族日記に記される住宅名の末尾語「亭」について、「第」 と比較しつつ検証した。検証結果の概要を以下にまとめる。 
(1) 10、11 世紀に「亭」は少なく「第」を多用する、という星氏 らの主張を再確認した。また「第」は高位貴族の邸に用いると されたが、『小右記』によれば「亭」でもそれは該当した。

(2) 11 世紀中頃より「亭」を多用する、というのも星氏らの主張 であったが、本稿でもそれを確認した。本稿では加えて、「亭」 の事例をみると、「第」と同様に居住者の位階は広範囲であっ た。

(3) 1100 年前後、寸なわち 11 世紀後半から 12 世紀前半頃が、末 尾語「第」から「亭」への転換期で、それ以降は、「亭」を「第」 より多用した。

(4) 12 世紀は「亭」が支配的になるとされていたが、『台記』『玉 葉』では「第」も用いていて、日記によってその傾向には濃淡 があった。

(5) 13 世紀は「亭」「第」のいずれかが優勢というわけではなく、 両方を同じように用いた。

(6) 『後二条師通記』『中右記』『殿暦』『山槐記』『葉』では、記 主の自邸には「第」よりも「亭」を多く用いるか、「亭」のみ を用いた。とくに「亭」を選択的に用いたと考えられるのは、 『玉葉』であった。

史書をもとにした筆者らの分析では、12 世紀後半が「第」から「亭」 への転換期であるとみなされた 3) 4)。しかし日記を対象にした本稿 の分析では、それより半世紀から 1 世紀早い、11 世紀後半から 12 世紀前半頃がその時期であった（3)）。また史書では、当初の「亭」 は、池・泉など「水」の存在で知られる邸に用いる可能性があった が、とくに 12 世紀後半以降に両者の関係は見出し難いと推論した。 これについては本稿でも判然とはしなかったが、12 世紀以降につい ては、「亭」「第」の両方を用いていることや、園池の不在で知られ る邸を末尾語「亭」と寸る事例もあることから湦 33 )、「亭」と「水」 との関係を見いだすことはもはやできない、と考えて差し支えない だろう。

13 世紀以降は「亭」「第」ともに用いたとはいえ (5))、しかし 11 世紀から 12 世紀にかけて、1100 年頃を境に「亭」を多用する傾向 にあったのはなぜだろう。

これに答えるのは容易ではないが、想起されるのは屋敷規模の縮 小化という時代の潮流である。東三条第や閑院など方一町を超える 大規模な邸宅が存在した一方で、摂関家をはじめとする上級貴族の 邸でさえ、院政がはじまるこのころより、屋敷の規模は縮小化の傾 向にあったとされる注 34 )。末尾語「亭」の多用化とあるいは関連寸 るのではなからうか。もとより「亭」とは、あずまやであり、池の ほとりの建物の意でもある注 35$)$ 。要は、大規模な建物を決して指さ ないのである。そしてそれは自邸には「第」よりも「亭」を用いる 日記にうかがえる、記主の心性とも慗がるように考えられる。

末尾語と屋敷規模との間に関連性がある、とまではいえないにせ よ、末尾語の背景に屋敷規模の変容がもしあるなら、「亭」や「第」 といった 1 文字に過ぎないとはいえ、貴族日記にあらわれるその動 向が、かれらの住まいの、この時期の趨勢を表徴していることにも なろう。

史書の分析では、『百錬抄』の 12 世紀後半以降に「亭」が頻出し、 この時期からはじまる『吾妻鏡』では「第」ではなく「亭」を多用 していたことを明らかにした 3）４）とくに後者について、鎌倉幕府
による編纂で、武家政権を中心に記すという、『吾妻鏡』の史書とし ての性格を反映したものではないかと推論したが、屋敷規模の縮小 化がその背景にあり、とりわけ鎌倉や京都における武家屋敷の登場 がこれに関わることも想定される。いずれにせよ推論の域を出るも のではなく、実態の解明は今後の課題である。

それにしても全体として末尾語の主流は「第」から「亭」へと入 れ替わり、「亭」を多用する時期を経た 13 世紀に、『猪涱関白記』が 「第」に固執し「亭」を一切用いない、というのは奇異にもみえる。

『勘仲記』もまた同じである。記主の個性、書き癖といってしまえ ばそれまでなのかもしれないが、住宅呼称の末尾語をめぐっては、 日記ごとのより詳細な分析と、一方で時代の範囲を広げつつ、さら に検証を進める必要があろう。

本稿は、 2020 年度関西大学大学院理工学研究科高度化推進研究費 による研究成果の一部を含む。

\section{参考文献}

1) Liu, Y: On the meaning change of the last word "Den" of Heian and kamakura period aristocracy residence, Journal of Architecture and Planning (Transactions of AIJ), Vol. 84 No. 765, pp. 2407-2415, 2019. 11 (in Japanese)

劉羽虹：平安・鎌倉時代貴族住宅の末尾語「殿」の意味変化について，日 本建築学会計画系論文集, 第 84 巻, 765 号, pp. 2407-2415, 2019. 11

2) Liu, Y. Fujita, M.: On the Semantic Changes of the last word "Den" in the History books of Heian and Kamakura period, Architectural Institute of Japan Kinki Branch, Vol. 59, pp. 441-444, 2019 (in Japanese) 劉羽虹・藤田勝也：平安・鎌倉時代の史書にみる末尾語「殿」の意味変化 について, 日本建築学会近畿支部研究報告集, 第 59 号・計画系, pp. 441444, 2019. 5

3) Liu, Y. Fujita, M.: A research on the term of residences "Tei" between the Japan and china- Comparison with "Tei"-, Architectural Institute of Japan Kinki Branch, Vol. 60, pp. 461-464, 2020 (in Japanese) 劉羽虹・藤田勝也：日中における住宅用語「亭」に関する研究一「第」と の比較を通して一, 日本建築学会近畿支部研究報告集, 第 60 号・計画系, pp. $461-464,2020.5$

4) Liu, Y: : On the last word "Tei" of aristocracy residences in Heian and Kamakura periods, Journal of Architecture and Planning (Transactions of AIJ), Vol. 86 No. 779, pp. 259-268, 2021. 1 (in Japanese) 劉羽虹：平安・鎌倉時代貴族住宅の末尾語「亭」について, 日本建築学会 計画系論文集，第 86 巻, 779 号, pp. 259-268, 2021. 1

5) Hoshi, Y. et al.: A research on the name of aristocratic residences written in their diary, Architectural Institute of Japan Tohoku Branch, Vol. 69, pp. 153-156, 2006. 6 (in Japanese)

星陽介ほか：貴族日記にみる住宅の呼称に関する研究，日本建築学会東北 支部，第 69 号，pp. 153-156，2006. 6

6) Miyata, M. et al.: A research on the name of aristocratic residences written in Gyokuyou, Architectural Institute of Japan Tohoku Branch, Vol. 68, pp. 183-186, 2005. 6 (in Japanese)

宮田充ほか: 『玉葉』における貴族住宅の呼称に関する研究, 日本建築学会 東北支部，第 68 号，pp. 183-186，2005. 6

7) Kuroita, K. and Kokushi TaikeiEdition: Kokushi TaikeiKugyo Bunin1.2 (Directoryof CourtNobles) Yoshikawa Kobunkan, 1971 (in Japanese)

黒板勝美, 国史大系編修会：国史大系公卿補任 1、2 篇, 吉川弘文館, 1971

8) Ota, S.: Research of Shindenzukuri, Yoshikawa Kobunkan, 1987 (in Japanese)

太田静六：寝殿造の研究，吉川弘文館， 1987

9) Kyoto City Archaeological Research Institute: Heiankyo sakyo nijo nibo jyucho ato (kayanoin), 2005 (in Japa-nese)

京都市埋蔵文化財研究所編：平安京左京二条二坊十町（高陽院）跡, 2005

10) Institute of Paleological Studies: Heiankyo Teiyo, Kadokawa shoten, 
1994 (in Japanese)

古代学研究所編集：平安京提要, 角川書店, 1994

11) Kyoto City Archaeological Research Institute: Heiankyo sakyo sanjo nibo jyucho (Horikawain) ato, 2007 (in Japanese)

京都市埋蔵文化財研究所編：平安京左京三条二坊十町（堀河院）跡, 2007

12) Ota, H.: Nihon kenchikushijosetsu, Shokokusha Publishing Co.,Ltd, 2009 (in Japanese)

太田博太郎：日本建築史序説 増補第三版, 彰国社, 2009

13) Morohasi, T.: Dai Kanwa Jiten, Taishukan Publisher. 1994-2000 (in Japanese)

諸橋嘾次：大漢和辞典（修訂版），大修館書店，1994-2000

注

注1）各日記は以下の刊本による。大日本古記録 :『小右記』『中右記』『後二 条師通記』『殿暦』『思昧記』『猪隈関白記』『岡屋関白記』『民経記』『王 葉』、史料纂集 :『台記』『勘仲記』、増補史料大成 :『権記』『春記』『水 左記』『帥記』『兵範記』『山槐記』、『明月記 (全 3 巻)』国書刊行会、 今川文雄校訂『玉炭』思文閣出版、図書寮叢刊『仙洞御移徙部類記 上・ 下』明治書院。またあわせて下記を参照した。増補史料大成:『小右記』 『中右記』『台記』『勘仲記』、国書双書刊行会編『玉葉 (全 3 巻)』名 著刊行会。さらに末尾語「亭」「第」の事例抽出に、東京大学史料編纂 所および国際日本文化研究センター、国立歴史民俗博物館の公開デー タベースを活用した。なお本稿の注記における史料引用文中の〈〉は 割注を示す。

注2）ただし「左府亭」は、『玉萩』建暦元年 (1211) 3 月 4 日条に記される、 『小右記』長保元年 (999) 2 月 9 日条からの抄出による。大日本古記 録『小右記 11 小右記逸文 附載』の「小右記逸文」長保元年 2 月に も収載。

注3）「関白書亭」は万寿 2 年 (1025) 3 月 18 日条の「又関白書亭令会儒士 作文云、」、書亭」は万寿 4 年（1027） 6 月 2 日条の「今曉女院渡給関 白第、〈書亭〉」である。いずれも関白邸内の建物の可能性がある。

注4）藤原資頼は小野宮実資の養子で、阿波権守、弾正少饴、伯者守、刑部少 輔を歴任、『尊卑分脈』に正四位下とある。

注5）たとえば藤原頼通の「関白亭」は高陽院で、広大な池跡を検出（参考文 献 8)。源顕房（1037-1094）の「六條亭」は左京六条三坊五町に所在 し、邸内に名泉が湧き出し、「六条池亭」とも呼ばれていた（参考文献 9)。藤原敦家（1033-1090）の「敦家朝臣六條亭」が所在した左京六条 三坊十二町付近の地下は、発掘調査によれば平安時代から江戸時代ま で湧水層にあたるという（参考文献 9)。藤原師実の「堀河亭」は左京 三条二坊九 ・十町に所在し、白河天皇の里内裏時に池の存在が知られ る(参考文献 10)。藤原実季の「七条亭」は左京七条三坊十二町にあっ て、「七条水閣」とも呼ばれていた（参考文献 9)。そのほか藤原師通の 「二条亭」、「高松亭」、修理大夫俊綱朝臣臥見亭」にも「水」の存在が 知られる。

注6) 元永元年 (1118) 12 月 15 日条「京御所三条烏丸亭」、大治 2 年 (1127) 1 月 14 日条「三条烏丸第」。

注7）源基綱（従三位）の「左大弁雖来亭」、源雅実（正二位、従一位）の「内 大臣亭」「土御門亭」「内府土御門亭」、藤原長実（正四位下）の「八条 亭」、藤原忠長（正四位下）の「阿波守三条亭」、藤原基隆（正四位下） の「大宮亭」「磨守基隆朝臣大宮亭」「基隆三条亭」など。

注8）藤原頼長（正二位、従一位）の「左府亭」「左府御亭」「左府御分学生亭」 「東三条亭」、源雅定（正二位）の「右府中院亭」「定右府御亭」「中院 亭」「右府亭」「定亭」、藤原実能（正二位）の「内府亭」「三条西洞院内 府亭」、藤原宗能（正二位）の「権大納言亭」「上卿大納言宗能卿亭」、 藤原実行（従一位）の「太政大臣亭」「太政大臣三條高倉亭」「太相国御 亭」、大江維順（正四位下）の「大学頭亭」、藤原実綱（正四位下）の「式 部大輔実綱朝臣亭」、藤原正家 (正四位下) の「大輔正家亭」、藤原宗輔 (正二位) の「民部卿亭」、藤原基実（正二位）の「内府亭」、源定房（正 四位下) の「春宮亮亭」、藤原公教 (正二位) の「内府亭」「高倉内府亭」、 藤原伊通（正二位）の「左府亭」、藤原顕長（正四位下、正三位）の「頭 中宮亮三条西洞院亭」「八条堀川前中納言亭」、藤原重通（正二位）の 「按察使亭」、藤原成頼（従三位）の「成頼卿土御門亭」、平清盛（正二 位、従一位）の「六波羅亭」「内府六波羅亭」「内府亭」「前太相国亭」 「六波羅入道亭」、藤原邦綱（正三位）の「東三条亭」「土御門東洞院春 宮権大夫亭」、藤原経宗（正二位）の「左府亭」「左大臣亭」、藤原忠雅 (正二位、従一位) の「内府亭」「華山院太相国亭」「太政大臣亭」、藤
原師長（正二位）の「藤大納言亭」「検校藤大納言亭」「検校大納言亭」 「左大将亭」「検校左大将亭」、源雅通（正二位）の「源大納言亭」「内 府亭」、藤原基房（従一位）の「摂政亭」、平重盛（従二位）の「春宮大 夫亭」「六波羅前大納言亭」、藤原兼実（正二位）の「四条坊門東洞院右 府亭」「六角東洞院亭」「六角東洞院右府亭」「右府亭」、藤原実定（正二 位）の「皇后宮大夫亭」、藤原宗家（正三位）の「中御門西洞院権中納 言泉亭」、平時忠 (正三位) の「長官権中納言右衛門督平朝臣亭」など。

注9）藤原公能（正三位）の「権中納言公能第」、藤原頼長（正二位）の「宇 治小松第」、藤原忠通（従一位）の「摂政第」「摂政近衛第」「太政大臣 第」、高階仲行（従五位上）の「仲行六条万里小路第」、藤原実能（正二 位）の「右大将第」「右大将大炊第」「内大臣三條西洞院第」、藤原実行 (正二位、従一位) の「右大臣三条高倉第」「太相国第」、藤原隆季（正 四位下) の「左馬頭隆季朝臣室町第」、源雅定（正二位）の「右大臣第」

「右大臣六條室町第」「右大臣六條鳥丸第」、源成雅（正四位下）の「大 相公三條第」など。

注10）藤原忠通の邸について、康治元年 (1142) 正月 16 日条、同年 7 月 6 日 条、康治 2 年（1143） 3 月 9 日条、天養 2 年（1145）４月 21 日条に 「摂政亭」。康治元年 (1142) 2 月 5 日条に「摂政里第」。久安 2 年 (1146) 12 月 16 日条、久安 3 年 (1147) 3 月 27 日条、久安 4 年 (1148) 10 月 8 日条、久安 6 年 (1150) 2 月 12 日条に「㩒政第」。久安 3 年 (1147) 3 月 20 日条に「摂政近衛亭」。久安 4 年 (1148) 6 月 26 日条に「摂政 近衛第」。久安 4 年 (1148) 8 月 9 日条「近衛亭」。同年 10 月 8 日条 「近衛第」。また源雅定の邸について、仁平元年（1151）11月 11 日条 に「右大臣第」、仁平 3 年 (1153) 正月 7 日条に「右大臣亭」。

注11）平清盛の邸は「八條亭」「六波羅亭」「入道大相国八條亭」「八條坊門櫛 笥二品亭」。また清盛が信任した藤原邦綱の邸は「大納言邦綱卿亭」「土 御門亭」「五條亭」。さらに清盛の異母弟、平頼盛の邸は「右衛門督頼盛 卿之亭」で、清盛の三男宗盛の邸は「右大将亭」「八條北高倉新亭」。そ して清盛の継室時子の同母弟、平時忠の邸は「大理亭」など。

注12）参考文献 4 。

注13）平重衝（正四位下）の「左馬頭重衝朝臣八条亭」、藤原経宗（従一位） の「左大臣亭」、平清盛（従一位）の「八条亭」「入道相府八条亭」、藤 原基房（従一位）の「関白亭」、藤原邦綱（正二位）の「正親町東洞院 亭」「五条東洞院亭」、藤原隆季（正二位）の「別当亭」、平頼盛（正二 位）の「頼盛卿八条亭」、藤原基通（従一位）の「捠政八条亭」「八条亭」 「五条東洞院摂政亭」、藤原定能（正三位）の「藤中納言定能卿樋口大 宮亭」、源頼朝（正四位下）の「五条亭」、藤原経宗（従一位）の「左大 臣大炊御門亭」「左大臣亭」「左府亭」「左大臣大炊御門富小路亭」、藤原 頼輔（従三位）の「頼輔入道雲林院亭」、藤原隆房（従三位）の「冷泉 万里小路亭」「冷泉亭」、藤原経房（正三位）の「経房卿亭」「一上亭」 「上卿経房卿亭」、藤原光長（従四位上）の「光長朝臣亭」、藤原実房 (正二位) の「上卿右大将亭」「左大臣亭」、藤原実定（正二位）の「右 府亭」「右大臣亭」、藤原能保（正三位）の「一条室町亭」、藤原兼雅（正 二位）の「右大臣亭」など。

注14）藤原邦綱（正四位下、正二位）の「邦綱卿正親町第」「五条第」、平清盛 (従一位）の「六波羅第」、藤原基房（従一位）の「摂政第」「関白第」、 平重盛（正二位）の「故内大臣六波羅第」「重盛卿六波羅第」、源通雅 (正二位) の「内府第」、藤原定能（従五位下）の「六条坊門大宮第」、 平時忠（従二位）の「時忠卿佐女牛東洞院第」、藤原経宗（従一位）の 「左大臣第」「左府第」、平頼盛（正二位）の「頼盛卿六波羅第」、平重 盛（正二位）の「故内大臣六波羅第」、藤原成親（正三位）の「成親卿 五辻第」、藤原基通（従一位）の「博陸第」「摂政第」「五条東洞院第」、 源経信（従四位上）の「経信卿第」、藤原経房（正三位）の「経房卿第」、 藤原忠親（正二位）の「内大臣第」など。

注15）「大宮亭」と「大宮第」、左大臣亭」と「左大臣第」、土御門亭」と「土 御門第」、「八條亭」と「八條第」、「関白亭」と「関白第」、「五條東洞院 亭」と「五條東洞院第」、摂政亭」と「摂政第」、閑院亭」と「閑院第」、 「大炊亭」と「大炊第」など。なお、これについては宮田氏らが指摘し ている (参考文献 5 )。

注16）藤原公光（従二位）の「前左衛門督亭」、藤原基実（正二位）の「摂政 亭」、藤原基房 (正二位) の「摂政亭」、藤原経宗 (正二位) の「右府亭」 「左府亭」「左相府亭」「頭権大夫能朝臣来向亭」、藤原光隆（正三位） の「治部卿亭」、藤原隆季 (正三位) の「左金吾亭」、平清盛（従一位） の「太相国六波羅亭」、藤原邦綱（正二位）の「邦綱六条亭」、高階経仲 (従四位上) の「経仲亭」。

注17）藤原兼雅（正二位）の「右府五条亭」、源通親（正二位）の「左金吾中 
院亭」、平頼盛（正二位）の「室町亭」、藤原定能（正二位）の「樋口大 宮大納言亭」、藤原基通（従一位）の「博陸亭」。

注18）源通親（正二位）の「内府亭」「土御門内府亭」、藤原信清（従二位）の 「右衛門督亭」、藤原頼実（従一位）の「前太相国大炊御門亭」「前太政 大臣亭」、源通光（正二位）の「左衛門督久我亭」、源定通（正二位）の 「土御門中納言亭」、藤原実氏 (正二位) の「右大将亭」「右大将冷泉亭」 「内府亭」、藤原家実（従一位）の「大相国亭」、藤原公継（従一位）の 「左府亭」、藤原家嗣（正二位）の「右大将亭」、藤原良通（正二位）の 「冷泉亭」など。

注19）範子内親王の「前斎院大炊御門第」「前斎院五辻第」、藤原殖子の「七条 院三条烏丸第」「七条院七条第」、唓子内親王の「六條第」「宣陽門院六 條第」「大町宣陽門院第」「正親町宣陽門院第」、亮子内親王の「殷富門 院仁和寺第」「殷富門院安井第」、暲子内親王の「八条院八条第」、藤原 任子の「宜秋門院京極第」、礼子内親王の「四条壬生嘉陽門院第」など。

注20）藤原兼雅（正二位）の「右大臣里第」、源通親（正二位）の「内府第」 「内大臣中院第」、藤原基房（従一位）の「松殿禪門菩提院第」、藤原隆 忠（正二位）の「内大臣第」「中御門油小路内大臣第」「左大臣第」、藤 原頼実 (従一位) の「前太相国大炊御門第」「前太政大臣四条坊城第」、 藤原良経（従一位）の「故摂政中御門第」。

注21）『猪隈関白記』建暦元年（1211）1月 28 日条「今夜天皇自大内行幸於 前太相国大炊御門第、可為皇居也、」、『明月記』元久 2 年（1205） 3 月 27 日条「上皇・殷富院・仁和寺宮、渡御前太相国大炊御門亭、」。

注22）藤原能季（正四位下）の「能季朝臣中御門亭」、藤原隆忠（従一位）の 「左府亭」、藤原資頼（従三位）の「資頼朝臣亭」、藤原定高（従三位） の「二条中納言定高卿深草亭」、藤原良平 (正二位) の「左府亭広橋亭」、 西園寺公経 (従一位) の「太政大臣今出川亭」「入道相国亭」「今出川亭」

「入道相国今出川新亭」、藤原兼経（従一位）の「左府亭」「摂政亭」「近 衛亭」、近衛家実（従一位）の「前博陸亭」「前関白亭」、藤原行能（従 三位）の「行能卿里亭」、藤原良実（従一位）の「右大臣亭」、藤原親季 （正四位下）の「親季朝臣亭」、四条隆親（正二位）の「帥亭」「四条大 納言亭」など。

注23）藤原公継（正二位）の「内大臣第」、藤原能季（従三位）の「能季卿中 御門第」、藤原公経（正二位）の「右大将勘解由小路第」、源雅実（正二 位）の「内大臣土御門第」、藤原家成 (従三位) の「権大夫家成三条第」、 近衛家実 (従一位) の「博陸第」「猪熊第」、西園寺公経（従一位）の「太 政大臣入道今出川第」、藤原教実（従一位）の「摂政第」、藤原兼経（従 一位）の「左府第」「摂政第」など。

注24）藤原能季の「能季朝臣中御門亭」「能季朝臣中御門第」、西園寺公経の 「太政大臣今出川亭」「太政大臣入道今出川第」、近衛兼経の「左府亭」 「左府第」や、近衛家実の「猪熊亭」「猪熊第」。

注25）菅在高（正三位）の「在高卿上東門亭」、藤原公継（従一位）の「左大 臣三条亭」、藤原教実（正二位）の「一条亭」、北条泰時の「武州亭」、 藤原兼平 (正二位) の「右府亭」、藤原実基（正二位）の「冷泉万里小 路亭」、源顕平 (正二位) の「顕平卿春日万里小路亭」、源具実 (正二位) の「入道内大臣泉亭」、藤原隆親（正二位）の「隆親卿四条亭」、平時高 (従三位) の「時高卿安居院亭」など。

注26）藤原家実（従一位）の「大閤土御門第」、藤原実氏（正二位、従一位） の「内大臣冷泉富小路第」「冷泉第」「太政大臣冷泉第」「前相国冷泉第」 $\lceil 大$ 相一条北辺第」、藤原親俊（従二位）の「親俊卿四条第」、源顕平 (正二位) の「顕平卿春日万里小路第」、藤原兼平（従一位）の「左大 臣第」、藤原公経 (従一位) の「一条入道太相国第」、藤原隆親 (正二位) の「四条大納言第」など。

注27）源顕平の「顕平卿春日万里小路亭」「顕平卿春日万里小路第」、藤原（四 条）隆親の「隆親卿四条亭」「四条大納言第」や、西園寺実氏の「冷泉 亭」「冷泉第」。

注28）藤原師経（正二位）の「右府亭」、藤原基家（正二位）の「五辻大宮亭 「九条亜相亭」、近衛家実 (従一位) の「土御門堀川関白殿御亭」「関白 殿御亭」「土御門関白殿御亭」「土御門堀川御亭」、藤原（滋野井）実宣 (正二位) の「前大納言実宣卿亭」、藤原家時（従三位）の「三位家時 卿」、藤原家信（従三位）の「三位家時卿」、源兼時（正四位下）の「入 道修理権大夫兼時朝臣亭」、藤原道家（正二位）の「一条室町関白亭」 「一条町亭」「関白亭」、西園寺実氏（正二位、従一位）の「右大将亭」 「内府冷泉亭」「冷泉富小路内大臣亭」「内相国亭」「内府亭」「内大臣 亭」「冷泉富小路厳親相府亭」「冷泉富小路相府亭」「前相国亭」、藤原頼 房 (従三位) の、「綾小路堀川三位入道頼房卿亭」「綾小路堀川亭」、源 具実 (従二位、正二位) の「左衛門督具実卿亭」「堀川大納言亭」、藤原
（日野）家光（従三位）の「左大弁家光卿亭」、平範輔（従三位）の「右 大弁範輔亭」、藤原氏通（従四位下）の「大炊御門堀川少将氏通亭」、藤 原家衡（正三位）の「六條三位入道家衡卿亭」、藤原隆親（従二位）の

「四条納言冷泉亭」「万里小路亭」「四条大納言冷泉万里小路亭」「中宮 大夫亭」、藤原教実（正二位）の「関白亭」「今出川亭」、三条公房（従 一位）の「二条油小路浄土寺相国亭」「二条油小路亭」、西園寺公経（従 一位）の「今出川相国禅門亭」「相国禅門亭」「今出川大相国亭」「今出 川亭」「入道太政大臣亭」「今出川入道相国亭」「入道太相国亭」、藤原家 嗣（正二位）の「右大将亭」、藤原実親（従一位）の「三条前右府亭」 「前右府亭」、平経高（正二位）の「民部卿亭」、藤原（徳大寺）実基（正 二位）の「右大将徳大寺亭」、菅原淳高（従二位）の「刑部卿亭」、藤原 兼平 (正二位) の「一上亭」、藤原道良（従一位）の「二条富小路亭」、 藤原（西園寺）公相（従一位）の「一上亭」、藤原家良（正二位）の「衣 笠前内府亭」、源資定（正四位下）の「源相公亭」、藤原（花山院）定雅 (正二位) の「花山入道右府粟田口亭」など。

注29）藤原実氏（正二位）の「内大臣第」、藤原隆親（正二位）の「冷泉万里 小路亭」「兵部卿熟尾第」、西園寺実氏（従一位）の「太相国富小路第」 「吹田第」、藤原実親（従一位）の「三条入道右府第」、藤原実経（従一 位）の「一条室町関白殿里第」、藤原通雅（正二位）の「右大将第」、藤 原公孝（正四位下）の「新大理第」、藤原資宣（正五位上）の「右中丞 第」「頭弁第」、藤原実尚（正二位）の「八条納言第」、源具実（正二位） の「堀川内府入道第」、藤原基平（従一位）の「左府第」、藤原公孝（従 三位）の「大理第」。

注30）藤原隆親の「冷泉万里小路第」「冷泉万里小路第」や、西園寺実氏の「外 祖太相国富小路第」「冷泉富小路外祖前太相国亭」。

注31）源親時の「親時第」、藤原（世尊寺）経朝（正三位）の「三品第」「勘解 由小路三位第」「白川三品第」、源基具（正二位）の「堀川大納言第」、 藤原（日野）資宣（正三位、正二位）の「藤中納言第」「前藤中納言第」 「民部卿第」、藤原（吉田）経長（正四位下、正三位、従二位）の「吉 田第」「吉田中納言第」「吉田黄門第」「頭弁吉田第」、近衛家基 (正二位) の「内大臣殿御第」、源（中院）通成（正二位）の「内府禅門第」「三条 坊門万里小路内府禅門第」、菅原在匡（従四位上）の「刑部卿第」、広橋 兼頼（正四位下）の「頭弁殿第」、藤原（西園寺）実兼（正二位）の「春 宮大夫第」「西園寺大納言第」「春宮大夫西園寺第」、源（中院）通頼（正 二位）の「土御門源大納言第」、藤原（坊城）俊定（正五位下）の「吉 田俊定第」、源資平 (正二位) の「前源中納言第」「按察第」「按察卿第」、 藤原 (広橋) 兼頼 (正四位下) の「貫首大丞第」、藤原経持の「経持第」、 吉田経長（正三位）の「左大弁宰相河東第」、藤原（花山院）定雅（正 二位）の「栗田口禅閣第」、藤原（中御門）経任（正二位）の「中御門 亜相第」「帥卿第」「都督第」、藤原（大炊御門）信嗣（正二位）の「大 炊御門大納言第」、藤原公為（従三位）の「一条三位入道第」、藤原（松 殿）隆行（正二位）の「四条前中納言隆行卿春日万里小路第」、源（中 院）通成（正二位）の「三条坊門内府禅門第」、高経茂（従四位下、従 三位）の「一条小河第」「経茂卿第」、藤原 (二条) 師忠（従一位）の「万 里小路第」、源（堀川）基具（従一位）の「儀同三司基具公第」「儀同三 司堀川第」「一品堀川第」「儀同三司第」「一品第」、平信輔（正五位上） の「信輔朝臣第」、藤原 (花山院) 長雅 (正二位) の「花山院大納言第」、 源（土御門）定実（正二位）の「土御門大納言第」、藤原（葉室）頼親 (正二位) の「按察卿第」、四条隆親（正二位）の「大納言隆親卿四條 第」、藤原（三条）実重（正二位）の「前右大将第」、薄衣清堅（従六位 上）の「清堅朝臣第」など。

注32）平時継（正二位）の「深草前平納言亭」、源具房（正二位）の「中院黄 門亭」「中院中納言亭」、藤原（五辻）経氏（正四位下）の「頭中将経氏 朝臣亭」、藤原（吉田）経長（正二位）の「吉田亭」、西園寺実兼（正二 位）の「春宮大夫亭」、皇居の「四條亭」、「安居院公遠朝臣亭」。

注33）『中右記』元永元年（1118）正月 20 日条に「此御所依無前池」とある ように、「三条烏丸亭」に「前池」は不在である。また『兵範記』仁安 2 年（1167） 5 月 17 日条に「土御門東洞院春宮権大夫亭」と記される 藤原邦綱の邸について、『台記別記』久安 3 年（1147）3 月 27 日条は 「土御門北、東洞院東、無池山」とある。

注34）参考文献 8 の pp. $644-645$ 、参考文献 12 の pp.98、pp. $139-140$ 。

注35）参考文献 13 


\title{
ON THE LAST WORD “TEI” OF HEIAN AND KAMAKURA PERIOD ARISTOCRACY RESIDENCE IN
} THE NOBLE DIARY

\author{
Yuhong LIU ${ }^{* 1}$, Masaya FUJITA *2 \\ ${ }^{1}$ Grad. Student, Graduate School of Science and Engineering, Kansai University, M.A. \\ ${ }^{2}$ Prof., Kansai University, Dr.Eng.
}

The purpose of this research is to clarify the actual condition of the last word “Tei” (亭) of the residence name that can be seen in the noble diaries from Heian to the early Kamakura period in Japan. In this paper, in addition to the noble diaries featured by Hoshi et al., "Suisaki" "Sankaiki" "Gumaiki" "Kanchuki" and "Sentogoishiburuiki" are newly considered. It is also necessary to compare “Tei” (亭) with “Tei” (第).

Summarize the following research results.

(1) In the 10th and 11th centuries, I reaffirmed Hoshi et al.'s claim that “Tei” (亭) are few and “Tei” (第) is heavily used. Also, "Tei" (第) was said to be used for the residence of high-ranking nobles, but according to "Shoyuki", it was also applicable to “Tei” (亭).

(2) Hoshi et al. claimed that "Tei” (亭) was heavily used from the middle of the 11th century, this was confirmed in this paper. Furthermore, As seen from the cases of residences "Tei” (亭), the court rank of residents was widely as “Tei” (第).

(3) The around 1100, namely from the latter half of the 11th century to the first half of the 12th century, it was a transitional period from the last word “Tei” (第) to “Tei” (亭) of residences, Since then, “Tei” (亭) was used more often than “Tei” (第).

(4) In the 12th century, “Tei” (亭) was supposed to be dominant, but in "Daiki” and “Gyokuyo", "Tei” (第) is also used. And there was a difference in the tendency depending on the diaries.

(5) In the 13th century, either “Tei” (亭) or “Tei” (第) was not dominant, but both were used in the same way.

(6) In "Gonijomoromichiki" "Chuyuki" "Denryaku" "Sankaiki" and "Gyokuyo", the owner's residence uses more "Tei" (亭) than “Tei” (第), or only “Tei” (亭) was used. Specially “Gyokuyo”, that was thought to have used “Tei” (亭) selectively.

In the 13th century, it is unusual for sticking use "Tei" (第) and not use "Tei" (亭) at all in "Inokumakanpakuki". "Kanchuki" has the same tendency. May be influenced by the personality and writing habits of the writer. It is necessary to conduct detailed verification and analysis around “Tei” (亭) “Tei” (第) or the other residence words, and further expanding the times.

(2020 年 10 月 8 日原稿受理, 2021 年 1 月 18 日採用決定) 